\title{
Continuities in Capitalism: Exploitation of Indentured and Migrant Labour
}

$* * *$

Kevin De Silva is a third year student at the University of Toronto. He is completing his undergraduate degree in Political Science and

Caribbean Studies, winning in 2010 the United Network of IndoCaribbean Toronto Youths (U.N.I.T.Y.) Scholarship. He is a member of the Caribbean Studies Students' Union, and is chief editor of Caribbean

Quilt. He has also contributed to the Stabroek News in Guyana on issues concerning environmental politics and diaspora.

$* * *$

"Indentureship" is a legal, contractual agreement which defines a particular, temporally structured relationship involving capital interests and labour. The practical, historical results of such a contract required of labour its submission and unwitting acceptance of a subaltern state, ensuring the dominance of capital. In short, indentureship was a conceived as a legal compulsion demanding economic operationalization with punitive measures for those who resisted. If one accepts the practical implications of indentureship in these terms, one implicitly assumes a moral or normative position, that is, one automatically understands such a system to be reprehensible, exploitative, and "wrong." This position however is easy to take: since the period of indenture is in the Caribbean over, and since diasporic labour populations have been constituted under nation-states as "freemen" contemporarily, with the benefit of hindsight, a seemingly "clearcut issue" becomes fodder for arm-chair criticisms of past practices, institutions, and norms.

Yet the capitalist framework which underpinned this system still readily persists with only reticent moral condemnations of it. Destroying temporality, that is, viewing indentureship as a past phenomenon in its character, destroying regionalism, that is, viewing features of indentureship only in the purview of a quintessentially 
Caribbean experience, and destroying the nation-state as a level of analysis (ignoring flows of labour divorced from any meaningful origin elsewhere globally) all become central in viewing history as a continuing, discursive process, rather than merely a sum total of dead events irrelevant to the present age.

This paper will argue that indentured labour, though nonexistent in the Caribbean today and less apparent in the rest of the world, continues structurally in the form of migrant labour. The intention of this argument is to re-infuse and expand normative considerations beyond any nationalist or cultural limitations. Similarities between the two processes seemingly detached from one another can be brought to light by analyzing firstly persisting economic modalities then secondly persisting social modalities in the cases of the Caribbean, India and the United Arab Emirates.

\section{Persisting Economic Modalities: Contrasting Pre \& Post Indenture India}

Basdeo Mangru describes Indian government policy during the period of indentured emigration as "largely influenced by the laissezfaire theory of administration... [with] minimum government interference in the pursuit of individual economic interests and few restrictions on the movement of goods, labour and capital." ${ }^{\text {The Indian }}$ government policy today, adapted formally in 1991, is one that stresses this continuance of the laissez-faire attitude in neo-liberal terms: freeing up markets, the redirection of government expenditure away from public services in favour of infrastructure which in turn is meant to guide and regularize capital movement, as well as privatization, competition and the promotion of foreign direct investment. This economic schema, aside from myths which stress the newness and uniqueness of it and its "globalization" presently, can be found in its earlier incarnations during the $19^{\text {th }}$ century: "Nineteenth century globalization involved increasing transfers of commodities, people, capital and ideas between and within continents. The most straightforward measure of integration is simply the growing volume of these international flows." 2 


\section{Kevin De Silva - CONTINUITIES IN CAPITALISM: EXPLOITATION OF INDENTURED \&}

MIGRANT LABOUR

India itself has historically been home to what is termed "surplus labour" (that is, a large swath of the population which, because of the inability of the land to accommodate more people"3) requires their literal outflow in the form of migration and economic operationalization. The latter point refers to the lack of an ability to compete agriculturally within the nexus of capitalist accumulation against capital-intensive foreign goods (such as British textile outputs in the $19^{\text {th }}$ century). Hence, a once agrarian population is pressured onto the labour market to satisfy the demands of industrial production elsewhere off of the hinterland. Although indebtedness was prevalent during the time of indentureship with "the ownership of...land passed to money-lenders; and as the traditional cultivators lost their land, the number of landless peasants increased," suffers the ills of indebtedness as a tool of economic, and in turn, social control. Migrant labour may at a glance seem to imply a type of "freeness" due to its spatial dimension; however "neo-bondage" compels workers into an equally subaltern state as the historicized indentured worker since they are not in a position to bargain in favour of what they deem reasonable payment for their work.

Neo-bondage specifically refers to the practice of a jobber "tying in prospective labourers through loans/ advances given during the lean season before the start of the seasonal employment relation." This effectively means that throughout the actual period of work, labourers are paid a minimal amount with the promise of the full amount to be doled out at the end of the campaign. Here, an obvious problem can be anticipated: that is in practice, labourers often do not receive accurate payment for their productive output, specifically through employers consciously manipulating the numbers to be paid to workers. Moreover this veiled practice leads to another problem - since only a minimum amount is paid during the period of seasonal employment, indebtedness may, and often does accrue without the labourers knowledge, forcing him or her to stay on even longer in order to simply pay off their debt. ${ }^{6}$

Walter Look Lai notes a central push factor for migratory indentureship from 1860 to 1879 was geographic as well as environmental, that is, "intense famine caused by crop failures or the 


\section{CARIBBEAN QUILT | 2011}

ravages of nature (drought or floods)". ${ }^{7}$ These events seem, wrongly of course, relegated to the historical sphere, yet noting the continuing harshness of the Indian landscape becomes imperative to understand the phenomenon of migrant labour today. Look Lai in the historical record notes famines in regions such as Bengal, Bihar, and Orissa, places which contemporarily are persisting sites for mass droughts, occurring as often as once every five years. ${ }^{8}$

The ILO points out that since agriculture is largely dependent on "precipitation and distribution of rainfall" recurrence of drought "reduces the purchasing power of [a] large segment of the population;", again leading to the need for migration. Related to the reality of famine here is of course impoverishment, and the pre-indenture period was unfortunately not the only time in which poverty in India was rampant. It has been calculated as recently as 2004 that $27.4 \%$ of India (more than a quarter of India's population) is under the poverty line. ${ }^{10}$

The central argument favouring categorizing indentured labour as a uniquely exploitative phenomenon is its legal implications. On the one hand, the institutionalization of 'unfreedom' in the form of a contractual obligation became socially normalized for labourers, in other words, coercion or exploitation did not seem at the time necessarily evident or apparent. Since the relationship was in its scope theoretically an agreement between two "equal" parties, an interpretation of "unfreedom" might have been felt, but not clearly discerned or understood by those involved. Nevertheless a contemporary interpretation of such a practice adamantly posits not only exploitation, but a relationship in many ways reminiscent in character to that of slavery. In order to expand this normative position it becomes necessary to situate terms such as freedom and unfreedom differently, outside of legal parameters exclusively. Neo-bondage, although not in any way related to the law, can be interpreted as a means of ensuring a cycle of subordination within a new framework, namely the market-system. This is not to say that during the indentured period the market did not exist, but it was coupled by many forms of pre-capitalist behaviour; the use of corporal punishment to discipline the workforce is but one example. 
Kevin De Silva - CONTINUITIES IN CAPITALISM: EXPLOITATION OF INDENTURED \& MIGRANT LABOUR

By stringently regulating the pay cycle of employees, as well as manipulating the sum total of money owed to the worker and coercing them into longer work cycles, neo-bondage in the form of indebtedness can be seen as promoting a type of "unfreedom" even when such a relationship is neither legally impelled nor implied. In other words, the market as well as the underground economy (which is merely a reflection of the former's existence) is its own enforcing mechanism demanding strict labour control and subordination. Weber's analysis of capitalism as an "iron cage" is part of this reading surely, but in a more concrete sense labour movement itself is determined not so much by the law as it is by the demands of capitalist production, demands which in a very real sense enforce subservient social roles to those apart of its lowest rung.

\section{Persisting Social Maladies: Comparing the Historical Caribbean to the Modern UAE}

Plantation society can be described not only capitalist but also as a "total institution". ${ }^{11}$ This categorization takes the plantation as a space of seemingly effective hegemony in the form of hierarchical and authoritarian structures that over-arch and over-lap, subordinating docile bodies to its rule. In the case of the indentureship period, it in many ways was a continuation of the period of slavery in a new disguise, with the same economic imperatives at the base of the system. Haraksingh for example states "the assumptions and premises of slavery continued to inform management attitudes." 12 Look Lai recounts the description of a British writer, Edward Jenkins:

Take a large factory in Manchester, or Birmingham, or Belfast, build a wall around it, shut in it's people from all intercourse, save at rare intervals, with the outside world, keep them in absolute heathen ignorance, and get all the work you can out of them, treat them not unkindly, leave their social habits and relations to themselves, as matters not concerning you who make money from their labor, and you would have constituted a little community resembling to no small degree, a sugar estate village in British Guiana ${ }^{13}$ 
The freedom of movement, something which may be overlooked and understated, was for the indentured worker severely limited as $\mathrm{s} / \mathrm{he}$ was expected to stay on the estate at all times. The consequences of disobeying this rule were "floggings and beatings" as well as "arbitrary fines and court sanctioned imprisonment." ${ }^{14}$ The limiting of space and saturation of the labourer with ceaseless work, hardship, and suffering must have created a culture somewhat adapted to severity. Nevertheless, the restriction of space also entailed the institutionalizing of a perpetual psychological torture for individuals who certainly must have had a yearning for their freedom.

According to Haraksingh, the driver also played a central role in the domination of the indentured worker, but not exclusively by physical means. The driver was able to command production because of his close ties to the "manager's ear" forcing Indians to act compliantly, and also because of his ability to dole out tasks with varying degrees of difficulty, in turn "enhancing their earnings." ${ }^{15}$ Look Lai notes that subjugation was further enhanced by the low wages Indian workers received ("in $1871 \ldots$ about $40 \%$ of male indentureds did not earn as much as $\$ 1.20$ a week"). ${ }^{16}$ This fact though seemingly detached from political/social control, was, in my view intimately tied to it. That is, maintaining low wages forced Indians to continue their servitude and labour for subsistence, with death following by both starvation and poverty if they did not accede to the dominating planter class.

Beating so-called "difficult" labourers, disallowing or preventing access to legal means of compensation, dwellings which were cramped and putrid, a lack of proper nutrition and sustenance as well as the continuation of poverty generally were all inherent features of indentured life in the $19^{\text {th }}$ century. With such a brutal historic record taken into account, it becomes instructive to contrast these realities with the contemporary case of migrant work in the United Arab Emirates.

The UAE, now one of the most developed countries in the world according to the HDI (Human Development Index), has risen as a world leader in finance as well as "development" for three primary reasons: oil, construction, and migrant labour. The government, pragmatically realizing that oil, because of its finitude needs to be instrumentally used as a means to an end in order to avoid a potential boom-bust cycle, has 
invested instead in longer-term mass construction projects. Already many of these spectacular sites have garnered attention on the world stage: its man-made islands The Palm Jumeirah, its indoor ski resorts, the Burj Dubai, now the tallest man-made structure in the world, as well as a whole host of other hotels, skyscrapers and tourist attractions such as its own, unique version of Disneyworld and even Louvre museum.

Yet, as is often the case with postcard imagery, the shining, glittering exterior of any metropolis or nation-state superpower hides it's structurally related, opposite actuality, its grimy, sordid underbelly. During the indentured period, it was reported that when the reality of the confined journey was realized by those boarding the ship, many desperately committed suicide by jumping into the Hughli River. ${ }^{17}$ Such circumstances are unfortunately not relegated to history's dustbin. The BBC in 2005 reported the case of Arumugam Venkatesan, a migrant worker who hung "himself from the ceiling fan in his room in his labour camp" due to inhuman living conditions. ${ }^{18}$ One can imagine many more cases that are unreported, a testament to labour camps with "85 men in a nine-roomed house...bedrooms sleep[ing] eight, sometimes 12 people...bathrooms...squeezed into cupboards and shared by 25 men. ${ }^{19}$ The horror however is intensified in that these labour camps are often nowhere near the locations in which actual work takes place, but are instead situated in the desert sand, where the "wind fills the air with sand and dust that choke the lungs and sting the eyes." 20

A strong parallel between the historical plantation and the contemporary case of the UAE is the stifling of resistance and the disallowance of labour unions. According to Human Rights Watch migrant workers "comprise nearly 90 percent of the workforce in the private sector...and are denied basic rights such as freedom of association and the right to collective bargaining." 21 This inconceivable dismissal reveals the true concern of the Emeriti government: to create a society mirroring a combination of Las Vegas and Singapore, a site of concentrated capital physically embodied in a completely bourgeois class. Here the goal is the capitalist utopia, the dominating and hegemonic ideological and economic concern of the neoliberal era. Human Rights Watch highlights elsewhere "unlawful recruiting fees, 
broken promises of wages, and a sponsorship system that gives an employer virtually complete power over his workers." 22 Again, although no formal legal provisions are utilized to ensure subservience, these "extra-legal" means do entail severe exploitation. Nor is there a need for an enforcement mechanism of subjugation when one must cope already with "sweltering humidity...well above 32 degrees Centigrade [perpetuating]...heat related illnesses", and employers "failing to pay for electricity, garbage and sewage collection in labour camps" as well as threatening deportation for striking. ${ }^{23}$ Though courts have formally called for the implementation of certain labour standards to be followed by employers, their refusals to acquiesce with such declarations are themselves commonplace practices in the United Arab Emirates.

\section{Conclusions}

In his book, In Defense of Lost Causes, Slavoj Žižek argues that the present neoliberal period is giving rise to a "growing apartheid," a widening separation between labour and its connection to a nation-state which would ensure at least an elementary level of legal protection against outside abuse. Slavery as well as indenturship are in my view early forerunners of such a thesis. The modern phenomenon of the export-process zone, or "fenced-in factories" outside any clear political jurisdiction are signifiers of transportable, interchangeable, and heavily guarded islands of freefloating capital. They impose, symbolically and literally, a type of purgatory onto a labouring citizenry that possess political rights only in an illusory sense, since they are, after all, owned and controlled by foreign agents, and not meaningfully connected to and protected by the polity they were born into. Žižek notes: "Since, sometime very soon, the urban population of the earth will outnumber the majority of the rural population, and since slum inhabitants will compose the majority of the urban population, we are no way dealing with a marginal phenomenon." ${ }^{24}$ Some questions emerge: Is such a pattern sustainable? What will happen to migrant labourers in countries such as the United Arab Emirates after the "boom of building" subsides? Can we not view 
slavery/indentureship and migrant labour as related institutionally, as "historical bookends" within the same overall capitalist schema? In order to even attempt to answer these questions fully one must, to restate, destroy temporality. One should not read history as detached or distant, meaningless and dead. One should instead trace its continuities, its changes and the cloaks its "movers" have adapted in charting a specific course. If indentured labour can be read as a cloaked "slavery," then, as this paper has argued, migrant labour certainly can be read as a continuation of indentureship.

\section{NOTES}

${ }^{1}$ Mangru, Basdeo. "Indian Government policy towards indentured labour migration to the sugar colonies." Benevolent Neutrality: Indian government policy and labour migration to British Guiana, 1854-1884. London: Hansib Pub Ltd, 1987. 162.

${ }^{2}$ Guillaume Daudin, Matthias Morys and Kevin H. O'Rourke.

"GLOBALIZATION, 1870-1914." University of Oxford Department of Economics Discussion Paper Series (2008): pp. 2.

${ }^{3}$ Bisnauth, Dale. "Chapter Three: Crossing the Kala Pani." Settlement of Indians in Guyana, 1890-1930 . Peepal Tree Press Ltd., 2001. pp. 38.

${ }^{4}$ Ibid.pp. 39.

${ }^{5}$ Lerche, Jens. "A Global Alliance against Forced Labour? Unfree Labour, NeoLiberal Globalization and the International Labour Organization." Journal of Agrarian Change, Vol. 7 No. 4 (October 2007): pp. 439.

${ }^{6}$ Ibid.

${ }^{7}$ Look-Lai, Walter. "Chapter 2: Push Factors and Migration Trends in India and China." Indentured Labor, Caribbean Sugar: Chinese and Indian Migrants to the British West Indies, 1838-1918. The Johns Hopkins University Press, 1993. pp. 25-26. 


\section{CARIBBEAN QUILT | 2011}

${ }^{8}$ Salve, Dr. W.N. Labour Rights and Labour Standards for Migrant Labour in India.

<http://www.ilo.org/public/english/protection/condtrav/pdf/rdwpaper22a.pdf>. pp. 7.

${ }^{9}$ Ibid.

${ }^{10}$ Patnaik, Utsa. "POVERTY AND NEO-LIBERALISM IN INDIA." Centre for Economic Studies and Planning, Jawaharlal Nehru University (2006): pp. 17.

${ }^{11}$ Beckford, George. "Plantation society: Toward a general theory of Caribbean

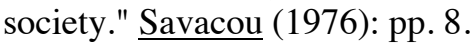

${ }^{12}$ Haraksingh, Kusha. "Control and Resistance among Indian Workers." Dabydeen, David. India in the Caribbean. Hansib/University of W Blication, 1987. pp. 67.

${ }^{13}$ Look-Lai, Walter. "Chapter 5: Life and Labour on the Plantations: The Indians." Indentured Labor, Caribbean Sugar: Chinese and Indian Migrants to the British West Indies, 1838-1918. The Johns Hopkins University Press, 1993. pp. 121.

${ }^{14}$ Ibid.

${ }^{15}$ Haraksingh, Kusha. "Control and Resistance among Indian Workers." Dabydeen, David. India in the Caribbean. Hansib/University of W Blication, 1987. pp. 69.

${ }^{16}$ Look-Lai, Walter. "Chapter 5: Life and Labour on the Plantations: The Indians." Indentured Labor, Caribbean Sugar: Chinese and Indian Migrants to the British West Indies, 1838-1918. The Johns Hopkins University Press, 1993. pp. 132.

${ }^{17}$ INDO CARIBBEAN: News Views and Information. INDIAN ARRIVAL IN THE CARIBBEAN. May 2003. <http://www.hansib-books.com/root/icn3.pdf>

${ }^{18}$ BBC NEWS I SOUTH ASIA. Migrants' woes in Dubai worker camps . 10 February 2005. <http://news.bbc.co.uk/2/hi/south_asia/4249223.stm>.

${ }^{19}$ Ibid. 
${ }^{20}$ World Socialist Website. The plight of the UAE's migrant workers: the flipside of a booming economy. 9 November 2007.

$<$ http://www.wsws.org/articles/2007/nov2007/duba-n09.shtml>.

${ }^{21}$ Human Rights Watch. "UAE: Address Abuse of Migrant Workers." 28 March 2006.

<http://www.hrw.org/en/news/2006/03/28/uae-address-abuse-migrant-workers>.

${ }^{22}$-. UAE: Exploited Workers Building 'Island of Happiness'. 2009 May 2009. $<$ http://www.hrw.org/en/news/2009/05/18/uae-exploited-workers-building-islandhappiness $>$.

${ }^{23}$ World Socialist Website. The plight of the UAE's migrant workers: the flipside of a booming economy. 9 November 2007.

<http://www.wsws.org/articles/2007/nov2007/duba-n09.shtml>.

${ }^{24}$ Žižek, Slavoj. In Defense of Lost Causes. New York, London: Verso , 2008. pp. 424. 